\title{
Diversity of Tiphiidae (Insecta: Hymenoptera) in the fragmented Brazilian semi-deciduous Atlantic Forest
}

\author{
Cíntia Eleonora Lopes Justino ${ }^{1}$ Eduardo Fernando dos $\operatorname{Santos}^{1}$ • \\ Fernando Barbosa Noll ${ }^{1}$
}

Received: 31 August 2015/Accepted: 3 May 2016/Published online: 7 May 2016

(c) Springer International Publishing Switzerland 2016

\begin{abstract}
The Atlantic Forest is one of the most important areas of biodiversity in the world, but it has been largely replaced with agropastoral areas and at the present only $12.5 \%$ of the original cover remains. Despite the ecological importance of insects, few studies have been used in conservation approaches for the Atlantic Forest, mainly due to a great taxonomic impediment. A group quite ecologically important but deeply neglected includes parasitoid wasps that control a great number of invertebrates, like tiphiid wasps that are parasitoids of underground coleopteran larvae. The present study aimed to estimate Tiphiidae species richness and diversity in 15 patches of a highly fragmented Atlantic Forest region, using factors that drive the diversity pool from a metacommunity, such as immigration and speciation probabilities. The parameters were estimated using the Neutral Biodiversity Theory, which is based on the total ecological equivalence of species at the same trophic level. Diversity values were molded to the area size, the immigration probabilities, and/or the speciation probability. Eight genera and 460 individuals of Thynninae, Myzininae and Tiphiinae were collected. Variation in species richness, estimated by both rarefaction and first-order jackknife methods, was explained by patch size and by immigration and speciation probabilities. These
\end{abstract}

Electronic supplementary material The online version of this article (doi:10.1007/s10841-016-9875-9) contains supplementary material, which is available to authorized users.

Cíntia Eleonora Lopes Justino

cintiaelju@gmail.com

1 Departamento de Zoologia e Botânica, Instituto de Biociências, Letras e Ciências Exatas, Universidade Estadual Paulista "Júlio de Mesquita Filho", Rua Cristóvão Colombo, 2265, Jd. Nazareth, São José do Rio Preto, SP 15054-000, Brazil variables also explained the variation in Shannon diversity and species evenness. Variations in species richness and diversity of Tiphiidae are strongly associated with neutral processes, but they are also influenced by forest fragmentation and intensive agricultural activities.

Keywords Parasitoids wasps - Tropical forest .

Agricultural landscape $\cdot$ Deforestation $\cdot$ Neutral model

\section{Introduction}

The Atlantic Forest is the second largest forest biome in South America (Ribeiro et al. 2009, 2011), and it is considered a hotspot of biodiversity since Meyer (1988), who first defined and described ten tropical forests as hotspots. Nowadays, 35 biodiversity conservation hotspots are recognized and the Atlantic forest is one of the most species rich areas on the planet (Ribeiro et al. 2011). The original cover of this biome was approximately 150 million hectares under highly heterogeneous environmental conditions, encompassing different habitats including deciduous and rain forests, mangroves, swamps, sand vegetation (restingas), inselbergs, high-altitude grasslands (campo rupestre and campo de altitude), and mixed Araucaria pine forests (Scarano 2002; Câmara 2003 in Ribeiro et al. 2011). However, currently, only $12.5 \%$ of the original cover remains (Fundação SOS Mata Atlântica and INPE 2002, 2014; Ribeiro et al. 2009).

Massive areas of Atlantic Forest are being reduced to an archipelago of small, widely separated forest fragments (Ranta et al. 1998), with approximately $97 \%$ of Atlantic Forest fragments having areas smaller than 250 ha (Ribeiro et al. 2009). Despite a dramatic reduction in Atlantic Forest deforestation since 2008 , more than 60,000 ha were lost 
between 2010 and 2013 (Fundação SOS Mata Atlântica and INPE 2014). The main cause of Atlantic Forest deforestation is agricultural expansion (Dean 1997), as in other tropical forests worldwide (Kaimowitz and Angelsen 1998; Sodhi et al. 2004; Pirard and Treyer 2010; Kissinger et al. 2012; Adu et al. 2012; FAO 2014). The resultant agro-mosaics now represent the predominant landscape type in formerly forested lands across the world (Sodhi et al. 2004; Tabarelli et al. 2010).

Forest fragmentation may be understood based on the basic conceptual model provided by island biogeography theory although this model has limitations and it cannot explain the dynamic that is greatly amplified in fragmented habitats (Haila 2002; Laurance 2008; Mendenhall et al. 2014). The island biogeography theory explains variation in species richness as a balance between immigration and extinction rates (MacArthur and Wilson 1963, 1967; Schoener 2010), which are also key components of the unified neutral theory of biodiversity and biogeography proposed by Hubbell (1997, 2001). The neutral theory treats the organisms of the same trophic level from a metacommunity ${ }^{1}$ as essentially identical in their individual probability of birth and death, immigration and speciation (Hubbell 2001; Mangel 2002; Bell 2001; Chave 2004). In addition, the neutral theory assumes that species are under no differential selection pressures (Hubbell 2001; Hubbell and Lake 2003), which means that species do not have different competitive ability and the diversity of a metacommunity is given stochastically by immigration, speciation, birth and death (Hubbell 2001; Mangel 2002; Chave 2004; Economo and Keitt 2008; Rosindell et al. 2011, 2012; Matthews and Whittaker 2014). Furthermore, it can robustly encompass the predictions of island biogeography theory, like species-area relationships (Rosindell et al. 2011).

The ratio between local births and immigration has an effect (decreasing or increasing) on the number of species coexisting in disturbed communities, which is important for ecosystem management and conservation (Dornelas 2010), whereas disturbance can increase the extinction rate and favor the dominance by a single species (Gardner and Engelhardt 2008). In this way, the neutral theory can be extended to explain patterns of species responses to disturbance (Kadmon and Benjamini 2006). The application of this theory in conservation approaches has the advantages of not requiring species-specific details, which are often lacking, and the inclusion of more intrinsic biological information linked to relative abundances rather than the extrapolation of species-area relationships (Rosindell et al. 2012).

\footnotetext{
${ }^{1}$ Metacommunity consists of all trophically similar individuals and species in a regional collection of local communities.
}

A great number of species remain unknown to science, especially those from hotspot biomes (Joppa et al. 2011) such as the Atlantic Forest. The insect fauna is a good example of that, despite of recent efforts to characterize it, our knowledge on its diversity remains incipient (Lewinsohn and Prado 2002; Lewinsohn et al. 2005; Rafael et al. 2009; Diniz-Filho et al. 2010) and many groups, such as the Tiphiidae wasps (Genise and Kimsey 1991; Kimsey 1991, 1992), have been neglected (Marinoni and Peixoto 2010). Tiphiidae is a cosmopolitan and diverse family (Pate 1947) of solitary and fossorial ectoparasitoid wasps of soildwelling beetle larvae (Brothers and Finnamore 1995; Pate 1947; Potter and Rogers 2008). The family includes more than 1500 described species representing 120 genera (Brown 2005). In Brazil, 102 species representing 19 genera have been described (Justino and Santos 2016). Tiphiidae wasps are mentioned as flower visitors and may be involved in pollination (Kevan 1973); furthermore, some species of Thynninae in Australia have a strong relationship with orchids as showed by Alcock (2000), Brown (1998), Handel and Peakall (1993), Mant et al. (2002, 2005), Peakall and Beattie (1996), Peakall et al. (2010) and Stoutamire (1983). Santos and Brandão (2011) and Santos et al. (2014) carried out the first characterizations of Tiphiidae diversity in the Atlantic Rain Forest, but the tiphiid fauna of Atlantic Semi-deciduous Forest is as yet largely unknown. Recent collections in patches of Semi-deciduous Forest have resulted in new records (Justino et al. 2013).

Regarding all of the aspects presented above, the present study aimed to answer the following questions: (1) How diverse is the Tiphiidae fauna in the Atlantic Semi-deciduous Forest? (2) Are the species richness and diversity of Tiphiidae affected by fragmentation of the Atlantic Forest fragmentation ? (3) Is the metacommunity structure of Tiphiidae driven by stochastic processes that underpin the unified neutral theory of biodiversity and biogeography, such as immigration and speciation?

\section{Materials and methods}

\section{Study area and collection methodology}

The present study was conducted in 15 forest fragments of different sizes (Table 1) from northwestern São Paulo State (Fig. 1). The landscape in this region consists of an agricultural matrix, which includes cane, citrus and coffee crops, and pasture (Table 1). Forest patches in northwestern São Paulo have been characterized as Semi-deciduous Seasonal Forest with different stages of ecological succession (Necchi Jr. et al. 2012). The climate in the region is defined as Temperate, with two distinct seasons (i.e., dry 
Table 1 Characteristics of the study area forest fragments: geographic coordinates, total size and surrounding matrix

\begin{tabular}{lllcl}
\hline Area & Latitude & Longitude & Size (ha) & Surrounding matrix \\
\hline Barretos & $20^{\circ} 29^{\prime} 05^{\prime \prime} \mathrm{S}$ & $48^{\circ} 49^{\prime} 21^{\prime \prime} \mathrm{W}$ & 885.5 & Pasture/sugarcane crops \\
Bebedouro & $20^{\circ} 53^{\prime} 06^{\prime \prime} \mathrm{S}$ & $48^{\circ} 32^{\prime} 26^{\prime \prime} \mathrm{W}$ & 397 & Pasture/sugarcane crops \\
Macaubal & $20^{\circ} 44^{\prime} 34^{\prime \prime} \mathrm{S}$ & $49^{\circ} 55^{\prime} 45^{\prime \prime} \mathrm{W}$ & 66.8 & Pasture/sugarcane crops \\
Magda & $20^{\circ} 28^{\prime} 25^{\prime \prime} \mathrm{S}$ & $50^{\circ} 17^{\prime} 36^{\prime \prime} \mathrm{W}$ & 1656.2 & Pasture/sugarcane crops \\
Matão & $21^{\circ} 37^{\prime} 14^{\prime \prime} \mathrm{S}$ & $48^{\circ} 32^{\prime} 14^{\prime \prime} \mathrm{W}$ & 2189.6 & Citrus crops/coffee crops \\
Novo Horizonte & $21^{\circ} 31^{\prime} 15^{\prime \prime} \mathrm{S}$ & $49^{\circ} 17^{\prime} 41^{\prime \prime} \mathrm{W}$ & 635 & Sugarcane crops \\
Palestina & $20^{\circ} 17^{\prime} 18^{\prime \prime} \mathrm{S}$ & $49^{\circ} 30^{\prime} 01^{\prime \prime} \mathrm{W}$ & 116.3 & Sugarcane crops \\
Planalto & $21^{\circ} 00^{\prime} 05^{\prime \prime} \mathrm{S}$ & $49^{\circ} 58^{\prime} 26^{\prime \prime} \mathrm{W}$ & 207.5 & Pasture/sugarcane crops \\
Pindorama & $21^{\circ} 13^{\prime} 12^{\prime \prime} \mathrm{S}$ & $48^{\circ} 55^{\prime} 04^{\prime \prime} \mathrm{W}$ & 107.8 & Pasture \\
Sales & $21^{\circ} 24^{\prime} 17^{\prime \prime} \mathrm{S}$ & $49^{\circ} 30^{\prime} 01^{\prime \prime} \mathrm{W}$ & 1799.6 & Pasture/sugarcane crops \\
Taquaritinga & $21^{\circ} 24^{\prime} 08^{\prime \prime} \mathrm{S}$ & $48^{\circ} 41^{\prime} 14^{\prime \prime} \mathrm{W}$ & 55.6 & Citrus crops \\
Turmalina & $20^{\circ} 00^{\prime} 13^{\prime \prime} \mathrm{S}$ & $50^{\circ} 26^{\prime} 02^{\prime \prime} \mathrm{W}$ & 108.3 & Pasture \\
União Paulista & $20^{\circ} 55^{\prime} 16^{\prime \prime} \mathrm{S}$ & $49^{\circ} 55^{\prime} 34^{\prime \prime} \mathrm{W}$ & 230.4 & Pasture/sugarcane crops \\
Vicentinópolis & $20^{\circ} 55^{\prime} 34^{\prime \prime} \mathrm{S}$ & $50^{\circ} 20^{\prime} 55^{\prime \prime} \mathrm{W}$ & 128.2 & Pasture/sugarcane crops \\
Votuporanga & $20^{\circ} 30^{\prime} 52^{\prime \prime} \mathrm{S}$ & $50^{\circ} 05^{\prime} 12^{\prime \prime} \mathrm{W}$ & 112.6 & Pasture/sugarcane crops \\
\hline
\end{tabular}

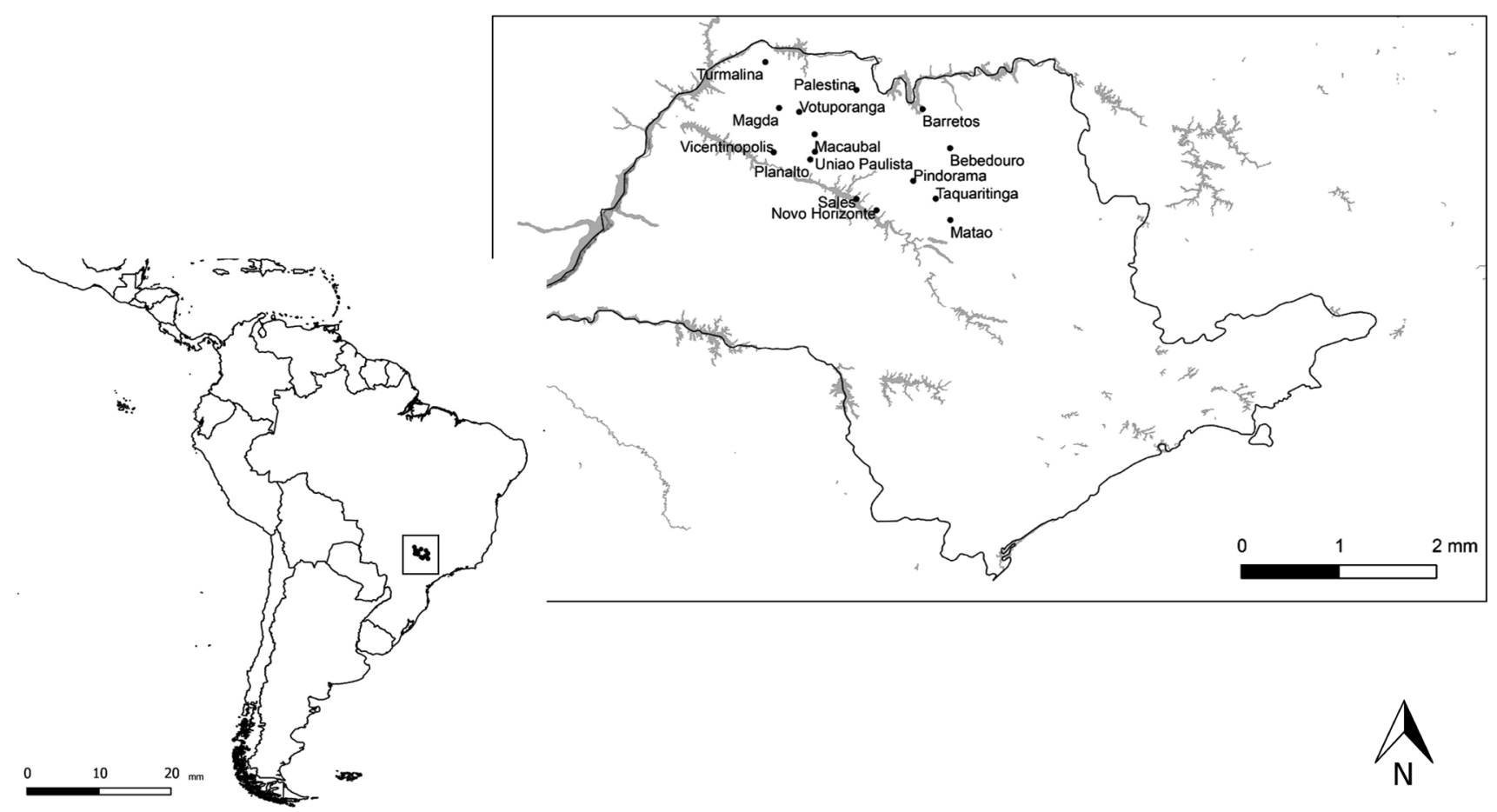

Fig. 1 Study area showing the locations of the 15 semi-deciduous forest patches. The lower left panel shows South America; circles within the boxed region represent the semi-deciduous forest patches.

winters and rainy hot summers), and temperatures higher than $22{ }^{\circ} \mathrm{C}$ (Peel et al. 2007).

The Tiphiidae fauna was sampled using a standardized sampling protocol that included placing two Malaise traps in each fragment from June of 2007 to November of 2009 (Table 1) totaling 60 samples from each fragment (30 days per trap). Bottles used in the Malaise traps were filled with
The upper right panel shows São Paulo state and the locations of the 15 semi-deciduous forest patches. The gray lines represent rivers

$70 \%$ alcohol and some drops of detergent to break the surface tension. The first trap was placed inside the patch $50 \mathrm{~m}$ from the edge, whereas the second trap was placed $50 \mathrm{~m}$ from the first, $100 \mathrm{~m}$ from the patch's edge. All of the specimens were pinned for identification by specialists and later deposited in the Hymenoptera collection of the Instituto de Biociências, Letras e Ciências Exatas da 
Universidade Estadual Paulista "Júlio de Mesquita Filho", Brazil. The number of specimens and species collected were counted for each sample and in total.

\section{Data analyses}

To describe the spatial variation in tiphiid diversity in the fragmented Atlantic Forest, some traditional parameters were estimated for each forest patch. Species richness was estimated by rarefaction and first-order jackknife methods, species evenness was estimated using Pielou's index $\left(J^{\prime}\right)$, and species diversity was estimated using the Shannon index $\left(H^{\prime}\right)$. The Shannon index ( $\log$ base $=2$ ), was chosen because it incorporates both species richness and evenness, and due to this it is possible to understand the influence of these two components on the species diversity. In addition, parameters of the neutral theory (Hubbell 2001), such as the Biodiversity Fundamental Number $(\theta$, see Hubbell (2001) for details), immigration probability $(m)$ (probability of the individual immigrating from a metacommunity, see Hubbell (2001) for details), and pointmutation peciation probability $(v)$ [probability of a new species arising in the local community, using the simplest speciation model, see Hubbell (2001), Etienne et al. (2007) and Kopp (2010) for more information], were estimated for each fragment using the classic neutral model that is characterized as being spatially implicit, since the exact spatial location of each individual was not considered (see Etienne and Olff 2005; He 2005; Etienne 2005; Rosindell et al. 2011, for details). The relationships of the parameter estimates with patch size were modeled using simple and multiple Generalized Additive Mixed Models (GAMMs). In the multiple models, $m$ and $v$ were treated as explanatory variables on a logarithmic scale. In addition, to model the variation in $\theta$, species richness and evenness were regarded as explanatory variables. Spatial correlation was included in all of the models, testing the five most used correlation structures: exponential, gaussian, linear, spherical, and rational quadratic. Moreover, the type of surrounding matrix was regarded as a random effect in all the models, i.e. possible influences of the surrounding matrix were eliminated to have more control on the relationships between the dependent and independent variables.

All of the statistical analyses were performed using the packages vegan version 2.2-1 (Oksanen et al. 2015), untb version 1.7-2 (Hankin 2015), mgcv version 1.8-4 (Wood 2014), and nlme (Pinheiro et al. 2015) for the program $\mathrm{R}$ version 3.0.1 (R Development Core Team 2013).

\section{Results}

In total, 460 individuals were collected in the 15 sampled fragments. They were from eight genera, 14 morphospecies and three subfamilies: Myzininae, Tiphiinae and Thynninae. Myzininae contains the third largest number of genera in the Tiphiidae (Kimsey 1991), Tiphiinae has a worldwide distribution (Allen 1972), Thynninae is distributed in the Neotropics and Australasia (Kimsey 1992, 2004) and is the largest subfamily in terms of the numbers of genera and species (Kimsey 1991).

The most abundant genus was Scotaena Klug (Thynninae), with 240 specimens collected. Upa Kimsey (Thynninae) and Myzinum Latreille (Myzininae) were the richest genera, represented by three species and morphospecies, respectively. Thynninae was the family with the most genera and species collected: Aelurus brasilianus Kimsey; Eucyrtothynnus Turner, Rostrynnus tarsatus Klug; Scotaena Klug, with possibly two different species; and three species of $U p a$ Kimsey: U. nasuta Kimsey 1996, U. porteri Kimsey 1996, $U$. tridentata Kimsey 1996. Only one individual of Eucyrtothynnus was collected in União Paulista, and only one individual of Rostrynnus tarsatus was collected in Sales. (Online Resource 1).

The rarefied species richness (RSR) was strongly related to the patch size and the immigration $(m)$ and speciation (v) probabilities (Table 2; Fig. 2). Based on the Akaike Information Criterion (AIC), the best-fitting model for the total species richness (TSR), as estimated by the first order jackknife, included only $m$ as an explanatory variable. In contrast, the ANOVA that was applied to this model and to the second best-fitting model, which includes the area, $m$ and $v$, indicated no differences between them (Likelihood Ratio $=5.541 ; P=0.236$ ), and due to this the most complete model (tsr $\sim$ area $+\log (\mathrm{m})+\log (\mathrm{v}))$ was preferred, since it explained almost $89 \%$ of the variation in the TSR (Table 2; Fig. 2).

Similar results were obtained from modeling the variation in Shannon diversity $\left(H^{\prime}\right)$. The model with the lowest AIC included only $m$ and $v$ (Table 2), but ANOVA revealed no significant difference between this model and the most complete one, that include area, $m$, and $v$ as explanatory variables (Likelihood Ratio $=0.8477$; $P=0.6545)$. Moreover, the most complete and secondbest-fitting model explained more of the variation in $H^{\prime}$ $(92.2 \%)$ than did the best-fitting model $(83.7 \%)$, and because of this the most complete model was preferred (Fig. 3). For species evenness, the model that included both $m$ and $v$ best explained $79.9 \%$ of the variation in this parameter (Table 2; Fig. 3). Additionally, the Fundamental Biodiversity Number $(\theta)$ was best modeled by the combination of patch size, species richness, species evenness, and immigration probability (Table 2; Fig. 4). Variation in the immigration and speciation probabilities was unrelated to the patch size variation (Table 2). The choice of the bestfitting spatial correlation structure was based solely on the AIC values (Online Resource 2). 


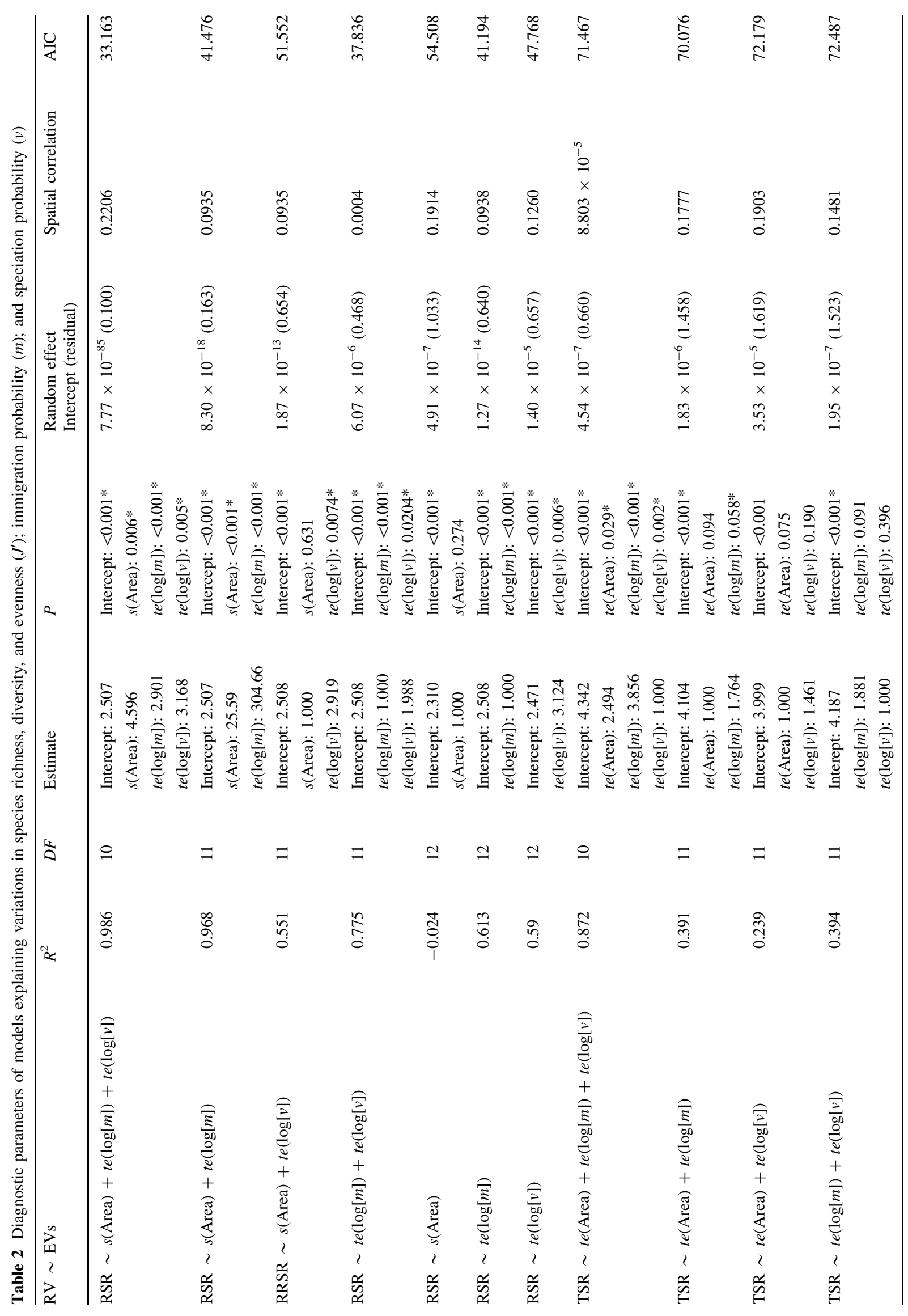




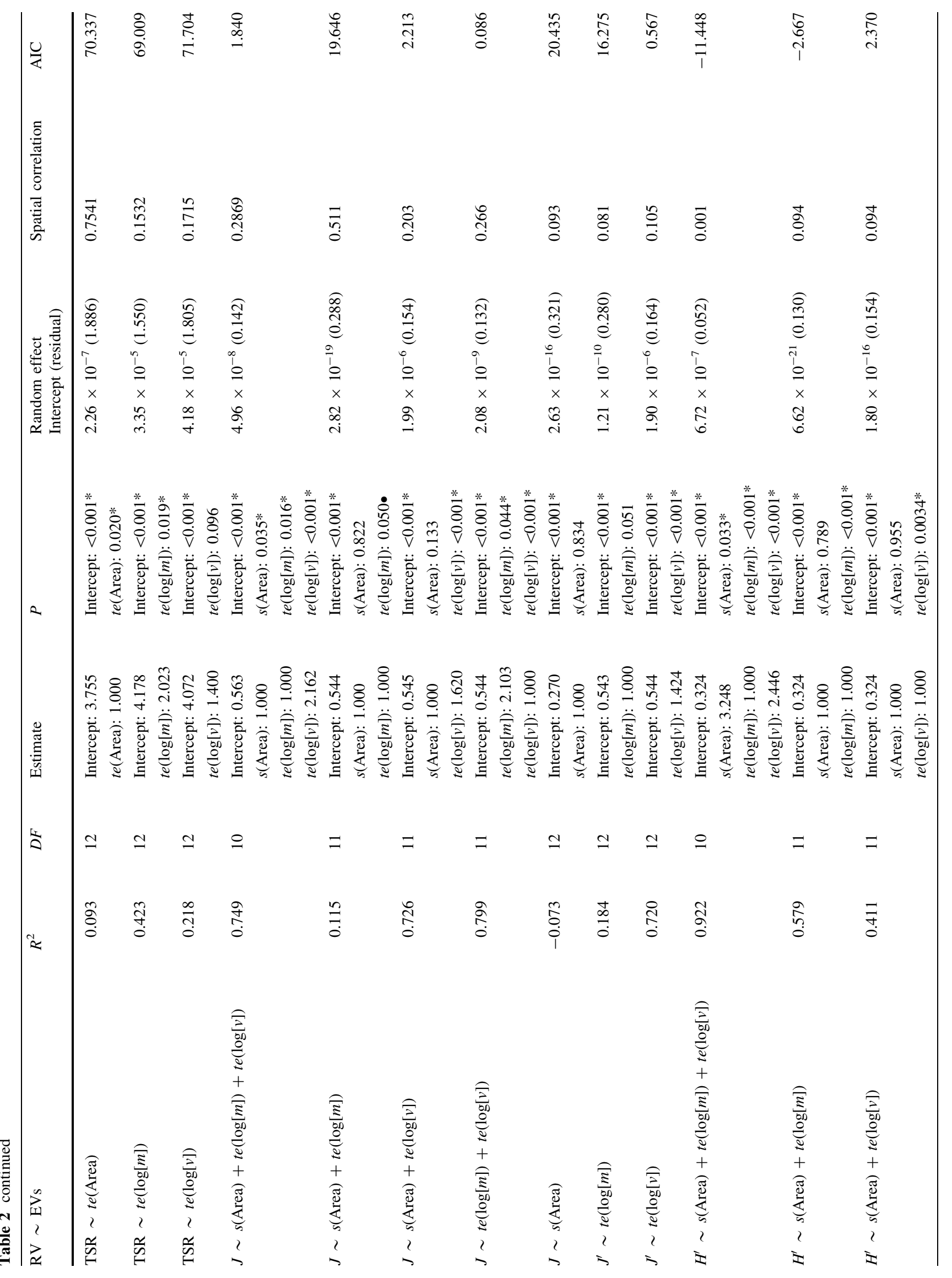














\section{Discussion}

The present study explored the variation in species richness and diversity as a function of patch size and variables that can be influenced by forest fragmentation, such as $m$ and $v$. The immigration rate is regulated by a neutral speciation-extinction process, whereas the probability of speciation reflects the rate at which a new species arises per individual propagation event (Hubbell 2001; Economo and Keitt 2008). Most studies based on neutral theory involve simulations, and few include empirical data.

In the present study, the sampled species richness (RSR) as estimated by rarefaction showed greater variation with respect to patch size, whereas the total species richness (TSR), as estimated by the first order jackknife, was more sensitive to $m$ and $v$ than to patch size. Some studies have demonstrated that $v$ and the dispersal distance affect species-area relationships (Durrett and Levin 1996; Zillio et al. 2005; Rosindell et al. 2011; Campos et al. 2012). Rosindell et al. (2011) proposed that $m$ is related to the mean dispersal distance, and Campos et al. (2012) noted that species-area relationships are less sensitive to $v$ in more fragmented habitats, suggesting that ecological drift is the mechanism underlying the generation of biodiversity in such habitats. According to Hubbell (2001), a community under ecological drift without immigration should gradually lose species over time because of local extinction.

One of the most recognized diversity patterns in ecology is that larger habitats support more species than do smaller ones (Rosenzweig 1995; Connor and McCoy 2001). However, the largest area of the present study presented a very low RSR, whereas some of the smaller areas showed high RSR and TSR values (Fig. 2). In contrast, the largest area showed a high TSR. Some studies have recorded an inverse relationship between species richness and the area of the forest fragment for different taxa (Carvalho and Vasconcelos 1999; Gascon et al. 1999; Ewers et al. 2007; Zipkin et al. 2009). Didham et al. (1998a, b) reported that the observed species richness and abundance of beetles (which are hosts to tiphiids) are equally high in small and large fragments and that they increase towards the forest edge, although rarefied species richness remains constant following fragmentation. Lövei et al. (2006) also found an inverse relationship between the species richness of beetles and forest area as a result of the edge effect. Didham et al. (1998a) noted that the edge effect on the species richness of beetles depends on individual density. Many parasitoids also show host density dependence, affecting their spatial distributions (May et al. 1981; Walde and Murdoch 1988; Rohani and Miramontes 1995; Hassell 2000). Price (1991) noted that host-parasitoid specificity is related to forest complexity, concluding that several species of idiobiont parasitoid per individual host can be found in forests of greater structural complexity because such forests can support a greater diversity of generalist species and impart stronger host density dependence, as is observed at forest edges compared to the forest core (Yahner 1988).

The positive consequences of the edge effect for community structure, including species richness, have been observed for different taxa (Carvalho and Vasconcelos 1999; Harper et al. 2005; Ewers et al. 2007; Zipkin et al. 2009). Consequently, the high species richness observed in some small fragments in the present study could be a result of the edge effect, as smaller forest patches suffer more from edge effects because of the higher ratio of edge per unit area (Didham et al. 1998a, b; Barbosa and Marquet 2002; Ewers et al. 2007). Edge effects are important drivers of change in many fragmented landscapes and depend on several abiotic and biotic factors that can be combined in different ways, characterizing the forest edge as an environment that is highly variable in space and time (Laurance et al. 2007).

In contrast, the low RSR observed in the largest area may be the result of pesticide application. This area is surrounded by a matrix that includes citrus and coffee crops, which commonly receive extensive applications of insecticides due to the large numbers of pests (Moguel and Toledo 1999; Belasque Jr. et al. 2010; Soares et al. 2013). Several studies have demonstrated that the use of such pesticides significantly reduces the regional biodiversity of invertebrates in natural ecosystems (Berendse et al. 2004; Beketov et al. 2013; Goulson 2013). In northwestern São Paulo State, insecticides are sprayed by airplanes, which can enlarge their area of action and strongly affect nearby natural ecosystems. In contrast, biological control has been used in sugarcane crops with desired efficiency and no negative impact in areas nearby (Parra 2014). Therefore, the low RSR observed in the largest area of the present study is potentially the effect of pesticide application in the surrounding matrix, although we do not have direct evidences for this. Clearly, this aspect should be considered in future studies.

The relationship between species diversity and area was similar to that observed between RSR and area, whereas species evenness showed a slight inverse linear relationship with area, decreasing with increasing area (Fig. 3). Considering that the Shannon index incorporates both species richness and evenness (Magurran 2004; Gotelli and Chao 2013), our results suggest that the faunistic heterogeneity in the study area is established primarily by the species richness. Metzger (1997) verified that species richness in the Semi-deciduous Atlantic Forest was correlated with fragment shape and connectivity, whereas species evenness was highly related to landscape composition and to the 



Fig. 2 Relationships of both sampled species richness (RSR) as estimated by rarefaction and the total species richness (TSR) as estimated by the first order Jackknife with patch size, $\log$ (immigration probability) and $\log$ (speciation probability)
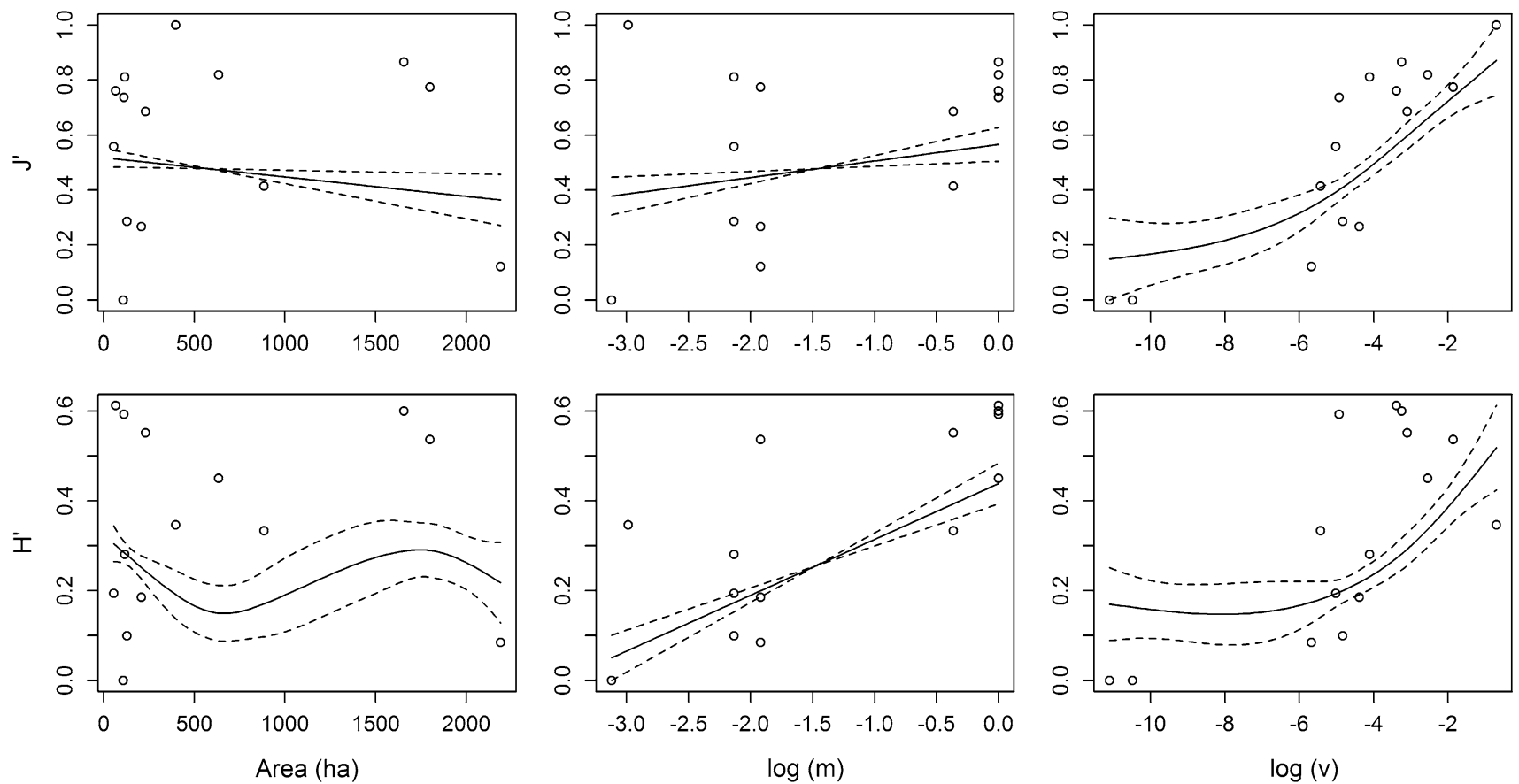

Fig. 3 Relationships of species evenness as estimated by Pielou's index and diversity as estimated by the Shannon index with patch size, $\log$ (immigration probability), and $\log$ (speciation probability)

spatial arrangement of forests, primarily the boundary complexity, and corridor and small patch (up to 0.72 ha) densities. Corridors are a significant component of effective biodiversity conservation systems, promoting the connectivity among fragments and allowing species immigration among formerly isolated patches (Mech and Hallett 2001; Tewksbury et al. 2002; Ayres et al. 2005; Rouget et al. 2006; Santos et al. 2008; Gilbert-Norton et al. 

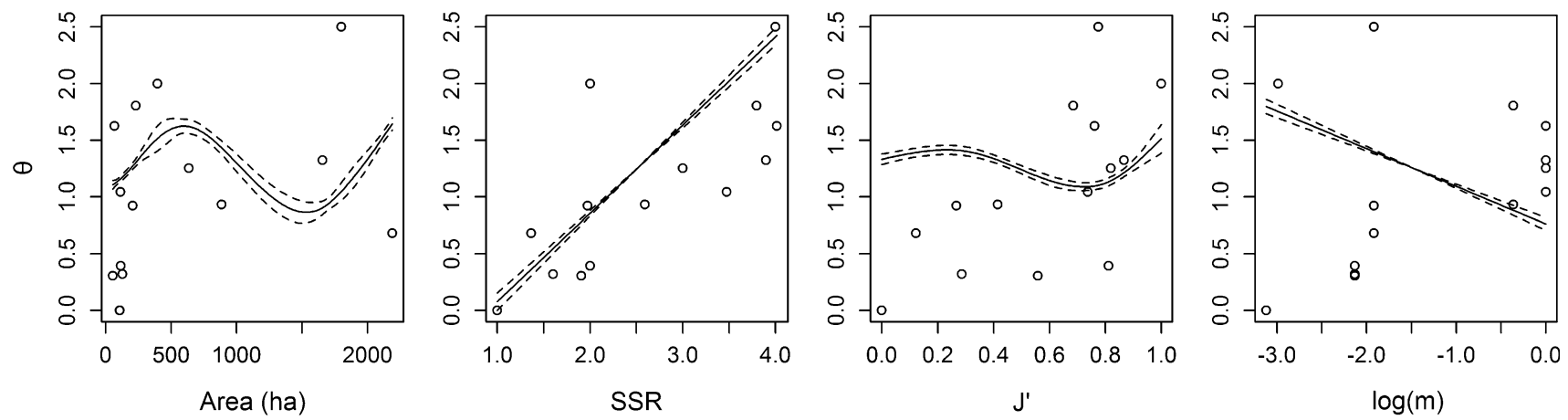

Fig. 4 Relationships of fundamental biodiversity number $(\theta)$ with patch size (Area), sampled species richness (RSR), log(immigration rate) and species evenness

2010; Tabarelli et al. 2010). Forest reduction has more dramatic consequences at high species dominance, decreasing it and altering the coexistence of species, so that species richness in an area increases with evenness whereas species dominance reduces the number of species ( $\mathrm{He}$ and Legendre 2002; Green and Ostling 2003; Hillebrand et al. 2008). Pereira et al. (2007) also found an increase in species evenness of plants with increasing severity of Atlantic Forest fragmentation. The relationship between species evenness of Tiphiidae and habitat fragmentation is conditioned by the immigration and, mainly, speciation probabilities (Table 2). This result corroborates the correlation between species evenness and corridor density found by Metzger (1997). High evenness arising from anthropogenic pressure will affect the magnitude and importance of intraversus interspecific interactions as well as community dynamics or processes that depend on the distribution traits in a community (Hillebrand et al. 2008).

Species evenness shows non-linear relationships between the Biodiversity Fundamental Number $(\theta)$ and area (Fig. 4). Moreover, based on the present results, $\theta$ is strongly and positively influenced by species richness and shows an inverse correlation with $m$. Even the largest area with low RSR showed relatively high values of $\theta$, whereas the smaller areas with relatively high RSRs presented low $\theta$ under the influence of $m$ and species evenness. According to Hubbell (2001), $\theta$ is determined as a function of community size and $v$ and represents the equilibrium between species richness and relative species abundance in a metacommunity. When individuals in a local community die, they are immediately replaced by offspring of other local individuals or by immigrants from the regional species pool, and the replacement probability by an immigrant is proportional to the abundance of each species in the metacommunity (Etienne and Olff 2005). Wilson and Hassell (1997) noted that the demographic stochasticity of host-parasitoid populations, as predicted by the neutral theory and incorporated in $\theta$, is established because slower dispersing parasitoids are unable to fix themselves in one precise location related to the host population; therefore, they go extinct because recolonization is unlikely, particularly when the metacommunity includes spatially isolated populations.

In the spatially implicit model, the diversity of a metacommunity is largely controlled by $\theta$, whereas the diversity of a local community is controlled by $\theta$, the local community size, and the immigration rate (Economo and Keitt 2008). Menz et al. (2013) verified that the more abundant and widespread species of Thynninae show shorter migration distances than do the less abundant and widespread species. The integrated use of the neutral and niche perspectives has been suggested as the best way to understand metacommunity dynamics (Leibold and McPeek 2006; Rosindell et al. 2012; Matthews and Whittaker 2014).

Wilson and Hassell (1997) described three stochastic factors that can influence the spatial dynamics of parasitoid metacommunities: (1) random dispersal by individuals, (2) random host encountering within a patch, and (3) a random number of individuals emerging from each host. These influences correspond to those predicted by the neutral theory. The random number of parasitoids emerging from each host and generation is inherent to the biology of the parasitoid species, and host encounters depend on random dispersal, as highlighted by Wilson and Hassell (1997). Dispersal rates are influenced by the proximity of localities, and spatial interactions between hosts and parasitoids assume a complete mixing of the dispersing individuals of both populations (parasitoid and host) such that the local instability of the host-parasitoid associations is established by asynchrony in extinctions and colonizations (Hassell 2000). The probability of extinction is directly linked with the relationship between hosts and parasitoids and distribution of the hosts among the patches (Comins et al. 1992). Concerning colonization, Elzinga et al. (2007) verified that colonization capacity is positively correlated with foraging 
distance. According to Hawkins and Gross (1992), parasitoids of root feeders, such as species of Tiphiidae, show a low colonization rate compared to species that attack more exposed herbivorous hosts.

Phillips et al. (2010) and Menz et al. (2013) verified that Thynninae males, the most representative group in the present study, undergo short foraging distances in response to sexually deceptive plant species. Females of this subfamily are wingless and spend much of their time underground (Ridsdill Smith 1970a, b; Osten 1999), and their mobility over long distances likely depends on the flying males, which transport and feed females during coupling (Ridsdill Smith 1970a; Osten 1999). As a result, the dispersal rate of Thynninae is correlated with and regulated by the food resources provided by flowers and the density of beetle larvae (Osten 1999; Menz et al. 2013). Moreover, the dispersal rate can be influenced by relationships with sexually deceptive plants, as observed in some Australian thynnines (Ridsdill Smith 1970a; Phillips et al. 2010; Menz et al. 2013).

In conclusion, the local species richness and diversity of the Tiphiidae in the fragmented Atlantic Semi-deciduous Forest of northwestern São Paulo State are, on average, slightly lower than the Atlantic Rain Forest's fauna, which was studied by Santos et al. (2014). Besides that, both species richness and diversity of Tiphiidae are strongly influenced by neutral processes as well as forest fragmentation and intensive agricultural activities. However, the spatial structure of the metacommunity is partially eroded due to fragmentation and patch isolation, which hamper individual dispersal. The use of corridors connecting fragments could potentially increase the dispersal rates of both hosts and parasitoids and consequently allow a stronger influence of stochasticity on habitat dynamics. Ecological corridors have been proposed as a key component of conservation planning as they can help maintain important ecological processes that play essential roles in biodiversity (Rouget et al. 2006). One of the main difficulties in the implementation of ecological corridors is that forest fragments often occur within private landholdings (Tabarelli et al. 2004; Rouget et al. 2006; Ribeiro et al. 2009), such that corridor implementation depends on agreements among landholders (Margules and Pressey 2000; Rouget et al. 2006). Our results show the importance of conservation of the remaining areas of Atlantic Forest that even in regions where the fragmentation level is high it concentrates a great diversity of species that are barely known. Most modern conservation strategies require the management of entire landscapes, including areas that are allocated to both production and protection (Margules and Pressey 2000; Shackelford et al. 2015). As discussed above Tiphiidae wasps can show close and important relationship with plants and other insects. Improving the knowledge in the richness and diversity of these wasps is essential to guarantee and help the conservation of the Atlantic Forest.

Acknowledgments We are grateful to the Laboratório de Aculeata Sistemática e Comportamento team, who helped us with the collection in the field, to Dr. Maria Stela Maioli Castilho Noll for a critical review of the manuscript and Dr. John Wenzel for reading the final version of this manuscript. The São Paulo Research Foundation (Fapesp) supported this study (Process Numbers: 2004/04820-3, 2008/09145-3 and 2009/16580-0).

\section{References}

Adu G, Marbuah G, Mensah JT (2012) Contribution of agriculture to deforestation in the tropics: a theoretical investigation. Afr Rev Econ Finance 3:1-12

Alcock J (2000) Interactions between the sexually deceptive orchid Spiculaea ciliate and its wasp pollinator Thynnoturneria sp. (Hymenoptera: Thynninae). J Nat Hist 34:629-636. doi:10.1080/ 002229300299480

Allen HW (1972) A monographic study of the subfamily Tiphiinae (Hymenoptera: Tiphiidae) of South America. Smithson Contrib Zool 113:1-76

Ayres JM, Fonseca GAB Rylands, Queiroz HL, Pinto LP, Masterson D, Cavalcanti RB (2005) Os corredores ecológicos das florestas tropicais do Brasil. Sociedade Civil Mamirauá, Belém

Barbosa O, Marquet P (2002) Effects of forest fragmentation on the beetle assemblage at the relict forest of Fray Jorge Chile. Oecologia 132:296-306. doi:10.1007/s00442-002-0951-3

Beketov MA, Kefford BJ, Schäfer RB, Liess M (2013) Pesticides reduce regional biodiversity of stream invertebrates. Proc Natl Acad Sci USA 110:11039-11043. doi:10.1073/pnas.1305618110

Belasque Jr. J, Yamamoto PT, Miranda MP, Bassanezi RB, Ayres AJ, Bové JM (2010) Controle do huanglongbing no estado de São Paulo, Brasil. Citrus Res Technol 31:53-64

Bell G (2001) Neutral macroecology. Science 293:2413-2418. doi:10. 1126/science.293.5539.2413

Berendse F, Chamberlain D, Kleijn D, Schekkerman H (2004) Declining biodiversity in agricultural landscapes and the effectiveness of agri-environment schemes. Ambio 33:499-502

Brothers DJ, Finnamore AT (1995) The vespoid families (except vespids and ants). In: Goulet H, Huber JT (eds) Hymenoptera of the world: an identification guide to families. Research Branch Agriculture Canada Publication, Otawa, pp 161-278

Brown GR (1998) Revision of the Neozeleboria cryptoides species group of thynnine wasps (Hymenoptera: Tiphiidae): pollinators of native orchids. Aust J Entomol 37:193-205. doi:10.1111/j. 1440-6055.1998.tb01572.x

Brown GR (2005) A revision of Tachyphron Brown and description of two new genera within the Ariphron group (Hymenoptera: Tiphiidae). J Nat Hist 39:197-239. doi:10.1080/0022290310001 657892

Câmara IG (2003) Brief history of conservation in the Atlantic forest. In: Galindo-Leal C, Câmara IG (eds) The Atlantic Forest of South America: biodiversity status, threats, and outlook. Island Press, Washington, DC, pp 31-42

Campos PRA, Neto EDC, Oliveira VM, Gomes MAF (2012) Neutral communities in fragmented landscapes. Oikos 11:1737-1748. doi:10.1111/j.1600-0706.2011.20336.x

Carvalho KS, Vasconcelos HL (1999) Forest fragmentation in central Amazonia and its effects on litter-dwelling ants. Biol Conserv 91:151-157. doi:10.1016/S0006-3207(99)00079-8 
Chave J (2004) Neutral theory and community ecology. Ecol Lett 7:241-253. doi:10.1111/j.1461-0248.2003.00566.x

Comins HN, Hassell MP, May RM (1992) The spatial dynamics of host-parasitoid systems. J Anim Ecol 61:735-748. doi:10.2307/ 5627

Connor EF, McCoy ED (2001) Species-area relationships. In: Levin SA (ed) Encyclopedia of biodiversity, vol 5, 2nd edn. Academic Press, Waltham, pp 397-411

Dean W (1997) With broadax and firebrand: the destruction of the Brazilian Atlantic Forest. University of California Press, Berkeley

Didham RK, Hammond PM, Lawton JH, Eggleton P, Stork NE (1998a) Beetle species responses to tropical forest fragmentation. Ecol Monogr 68:295-323. doi:10.1890/0012-9615(1998) 068[0295:BSRTTF]2.0.CO;2

Didham RK, Lawton JH, Hammond PM, Eggleton P (1998b) Trophic structure stability and extinction dynamics of beetles (Coleoptera) in tropical forest fragments. Philos Trans R Soc Lond B Biol Sci B 353:437-451. doi:10.1098/rstb.1998.0221

Diniz-Filho JAF, De Marco P, Hawkins BA (2010) Defying the curse of ignorance: perspectives in insect macroecology and conservation biogeography. Insect Conserv Divers 3:172-179. doi:10. 1111/j.1752-4598.2010.00091.x

Dornelas M (2010) Disturbance and change in biodiversity. Philos Trans R Scoc Lond B Biol Sci B 365:3719-3727. doi:10.1098/ rstb.2010.0295

Durrett R, Levin S (1996) Spatial models for species-area curves. J Theor Biol 179:119-127. doi:10.1006/jtbi.1996.0053

Economo EP, Keitt TH (2008) Species diversity in neutral metacommunities: a network approach. Ecol Lett 11:52-62. doi:10.1006/ jtbi. 1996.0053

Elzinga JA, van Nouhuys S, van Leeuwen D-J, Biere A (2007) Distribution and colonisation ability of three parasitoids and their herbivorous host in a fragmented landscape. Basic Appl Ecol 8:75-88. doi:10.1016/j.baae.2006.04.003

Etienne RS (2005) A new sampling formula for neutral biodiversity. Ecol Lett 8:253-260

Etienne RS, Olff H (2005) Confronting different models of community structure to species-abundance data: a Bayesian model comparison. Ecol Lett 8:493-504. doi:10.1111/j.1461-0248. 2005.00745.x

Etienne RS, Apol MEF, Olff H, Weissing FJ (2007) Modes of speciation and the neutral theory of biodiversity. Oikos 116:241-258. doi:10.1111/j.2007.0030-1299.15438.x

Ewers RM, Thorpe S, Didham RK (2007) Synergistic interactions between edge and area effects in a heavily fragmented landscape. Ecology 88:96-106

FAO (2014) State of the world's forests: enhancing the socioeconomic benefits from forests. http://www.fao.org/3/a-i3710e.pdf. Accessed 24 Jan 2015

Fundação SOS Mata Atlântica, INPE (2002) Atlas dos remanescentes florestais da Mata Atlântica: Período 1995-2000. http://mtcm12.sid.inpe.br/col/sid.inpe.br/jeferson/2003/06.02.07.45/doc/ RelatorioAtlas.pdf. Accessed 20 Feb 2015

Fundação SOS Mata Atlântica, INPE (2014) Atlas dos remanescentes florestais da Mata Atlântica: Período 2012-2013. http://mapas. sosma.org.br/site_media/download/atlas_2012-2013_relatorio_ tecnico_2014.pdf. Accessed 20 Feb 2015

Gardner RH, Engelhardt KAM (2008) Spatial processes that maintain biodiversity in plant communities. Perspect Plant Ecol 9:211228

Gascon C, Lovejoy TE, Bierregaard RO Jr, Malcolm JR, Stouffer PC, Vasconcelos HL, Laurance WF, Laurance B, Tocher M, Borges S (1999) Matrix habitat and species richness in tropical forest remnants. Biol Conserv 91:223-229. doi:10.1016/S0006-3207 (99)00080-4
Genise J, Kimsey LS (1991) New genera of South American Thynninae (Tiphiidae, Hymenoptera). Psyche 98:57-69

Gilbert-Norton L, Wilson R, Stevens JR, Beard KH (2010) A metaanalytic review of corridor effectiveness. Conserv Biol 24: 660-668. doi:10.1111/j.1523-1739.2010.01450.x

Gotelli NJ, Chao A (2013) Measuring and estimating species richness, species diversity, and biotic similarity from sampling data. In: Levin SA (ed) Encyclopedia of Biodiversity, 2sd, vol 5. Academic Press, Waltham, pp 195-211

Goulson D (2013) An overview of the environmental risks posed by neonicotinoid insecticides. J Appl Ecol 50:977-987. doi:10. $1111 / 1365-2664.12111$

Green JL, Ostling A (2003) Endemics-area relationships: the influence of species dominance and spatial aggregation. Ecology 84:3090-3097

Haila Y (2002) A conceptual genealogy of fragmentation research: from island biogeography to landscape ecology. Ecol Appl 12:321-334. doi:10.1890/1051-0761(2002)012[0321: ACGOFR]2.0.CO;2

Handel SN, Peakall R (1993) Thynnine wasps discriminate among heights when seeking mates: tests with a sexually deceptive orchid. Oecologia 95:241-245. doi:10.1007/BF00323496

Hankin RKS (2015) Package untb version 1.7-2: ecological drift under the UNTB. http://cran.r-project.org/web/packages/untb/ untb.pdf. Accessed 23 Feb 2015

Harper KA, MacDonald E, Burton PJ, Chen J, Brosofske KD, Saunders SC, Euskirchen ES, Roberts D, Jaiteh MS, Essen P-A (2005) Edge influence on forest structure and composition in fragmented landscapes. Conserv Biol 19:768-782. doi:10.1111/j. 1523-1739.2005.00045.x

Hassell MP (2000) The spatial and temporal dynamics of hostparasitoid interactions. Oxford University Press, Oxford

Hawkins BA, Gross P (1992) Species richness and population limitation in insect parasitoid-host systems. Am Nat 139:417423

He F (2005) Deriving a neutral model of species abundance from fundamental mechanisms of population dynamics. Funct Ecol 19:187-193. doi:10.1111/j.0269-8463.2005.00944.x

He F, Legendre P (2002) Species diversity patterns derived from species-area models. Ecology 83:1185-1198. doi:10.2307/ 3071933

Hillebrand H, Bennett DM, Cadotte MW (2008) Consequences of dominance: a review of evenness effects on local and regional ecosystem processes. Ecology 89:1510-1520. doi:10.1890/071053.1

Hubbell SP (1997) A unified theory of biogeography and relative species abundance and its application to tropical rain forests and coral reefs. Coral Reefs 16:S9-S21. doi:10.1007/s003380050237

Hubbell SP (2001) The unified neutral theory of biodiversity and biogeography. Princeton University Press, Princeton

Hubbell SP, Lake JK (2003) The neutral theory of biodiversity and biogeography, and beyond. In: Blackburn TM, Gaston KJ (eds) Macroecology: concepts and consequences. Blackwell Publishing, Oxford, pp 45-63

Joppa LOG, Roberts DL, Myers N, Pimm SL (2011) Biodiversity hotspots house most undiscovered plant species. Proc Natl Acad Sci USA 108:13171-13176. doi:10.1073/pnas.1109389108

Justino CEL, Santos EF (2016) Catálago Taxonômico da Fauna do Brasil. http://fauna.jbrj.gov.br/fauna/listaBrasil/ConsultaPubli caUC/ConsultaPublicaUC.do. Accessed 15 April 20016

Justino CEL, Santos EF, Noll FB (2013) Geographic note on species of the genus Upa Kimsey, 1991 (Hymenoptera: Tiphiidae, Thynninae) in the Atlantic Forest, Brazil. Check List 9:1057-1061

Kadmon R, Benjamini Y (2006) Effects of productivity and disturbance on species richness: a neutral model. Am Nat 167:939-946. doi:10.1086/504602 
Kaimowitz D, Angelsen A (1998) Economic models of tropical deforestation: a review. Center for International Forestry Research, Bogor

Kevan P (1973) Parasitoid wasps as flower visitors in the Canadian high arctic. Anzeiger für Schädlingskunde, Pflanzen- und Umweltschutz 46(1):3-7. doi:10.1007/BF01992960

Kimsey LS (1991) Relationships among the tiphiid wasp subfamilies (Hymenoptera). Syst Entomol 16:427-438. doi:10.1111/j.13653113.1991.tb00677.x

Kimsey LS (1992) Phylogenetic relations among the South American thynninae tiphiidae wasps. Syst Entomol 17:133-144

Kimsey LS (2004) Illustrated keys to genera of the male wasps in the subfamily Thynninae (Hymenoptera: Thiphiidae). Proc Entomol Soc Wash 106(3):571-585

Kissinger G, Herold M, De Sy V (2012) Drivers of deforestation and forest degradation: a synthesis report for REDD+ policymakers. Lexeme Consulting, Vancouver. https://www.gov.uk/govern ment/uploads/system/uploads/attachment_data/file/66151/Dri vers_of_deforestation_and_forest_degradation.pdf. Accessed 24 Jan 2015

Kopp M (2010) Speciation and the neutral theory of biodiversity. BioEssays 32:564-570. doi:10.1002/bies.201000023

Laurance WF (2008) Theory meets reality: how habitat fragmentation research has transcended island. Biogeographic theory. Biol Conserv 141:1731-1744. doi:10.1016/j.biocon.2008.05.011

Laurance WF, Nascimento HEM, Laurance SG, Andrade A, Ewers RM, Harms KE, Luizão RCC, Ribeiro JE (2007) Habitat fragmentation, variable edge effects, and the landscape-divergence hypothesis. PLoS One 2:e1017. doi:10.1371/journal.pone. 0001017

Leibold MA, McPeek MA (2006) Coexistence of the niche and neutral perspectives in community ecology. Ecology 87:1399-1410

Lewinsohn TM, Prado PI (2002) Biodiversidade Brasileira: síntese do estado atual do conhecimento. Editora Contexto, São Paulo

Lewinsohn TM, Freitas AVL, Prado PI (2005) Conservation of terrestrial invertebrates and their habitats in Brazil. Conserv Biol 19:640-645. doi:10.1111/j.1523-1739.2005.00682.x

Lövei GL, Magura T, Tóthmérész B, Ködöböcz V (2006) The influence of matrix and edges on species richness patterns of ground beetles (Coleoptera: Carabidae) in habitat islands. Glob Ecol Biogeogr 15:283-289. doi:10.1111/j.1466-8238.2005. 00221.x

MacArthur RH, Wilson EO (1963) An equilibrium theory of insular zoogeography. Evolution 17:373-387

MacArthur RH, Wilson EO (1967) The theory of island biogeography. Princeton University Press, Princeton

Magurran AE (2004) Measuring biological diversity. Blackwell Publishing, Malden

Mangel M (2002) The importante role of theory in conservation biology. Conserv Biol 16:843-844

Mant JG, Schiestl FP, Peakall R, Weston PH (2002) A phylogenetic study of pollinator conservatism among sexually deceptive orchids. Evolution 6:888-898

Mant JG, Brown GR, Weston PH (2005) Opportunistic pollinator shifts among sexually deceptive orchids indicated by a phylogeny of pollinating and non-pollinating thynnine wasps (Tiphiidae). Biol J Linn Soc 86:381-395. doi:10.1111/j.10958312.2005.00547.x

Margules CR, Pressey RL (2000) Systematic conservation planning. Nature 405:243-253. doi:10.1038/35012251

Marinoni L, Peixoto AL (2010) As coleções biológicas como fonte dinâmica permanente de conhecimento sobre a biodiversidade. Ciência e Cultura 62:54-57

Matthews TJ, Whittaker RJ (2014) Neutral theory and the species abundance distribution: recent developments and prospects for unifying niche and neutral perspectives. Ecol Evol 4:2263-2277. doi:10.1002/ece3.1092

May RM, Hassell MP, Anderson RM, Tonkyn DW (1981) Density dependence in host-parasitoid models. J Anim Ecol 50:855-865. doi: $10.2307 / 4142$

Mech SG, Hallett JG (2001) Evaluating the effectiveness of Corridors: a genetic approach. Conserv Biol 15:467-474

Mendenhall CD, Karp DS, Meyer CFJ, Hadly EA, Daily GC (2014) Predicting biodiversity change and averting colapse in agricultural landscapes. Nature 509:213-217. doi:10.1038/nature13139

Menz MHM, Phillips RD, Dixon KW, Peakall R, Didham RK (2013) Mate-searching behavior of common and rare wasps and the implications for pollen movement of the sexually deceptive orchids they pollinate. PLoS One 8:e59111. doi:10.1371/journal. pone.0059111

Metzger JP (1997) Relationships between landscape structure and tree species diversity in tropical forests of South-East Brazil. Landsc Urban Plan 37:29-35

Meyer N (1988) Threatened biotas: "hot spots" in tropical forests. Environmentalist 8:187-208

Moguel P, Toledo VM (1999) Biodiversity conservation in traditional coffee systems of Mexico. Conserv Biol 13:11-21. doi:10.1046/ j.1523-1739.1999.97153.x

Necchi O Jr, Branco LHZ, Casatti L, Castilho-Noll MSM, Feres RJF, Noll FB, Ranga NT, Rezende AA, Rossa-Feres DC (2012) Características da região noroeste do estado de São Paulo e dos fragmentos florestais remanescentes estudados. In: Necchi $\mathrm{O} \mathrm{Jr}$ (ed) Fauna e Flora de Fragmentos Florestais Remanescentes da Região Noroeste do Estado de São Paulo. Editora Holos, Ribeirão Preto, pp 15-36

Oksanen J, Blanchet FG, Kindt R, Legendre P, Minchin PR, O'Hara RB, Simpson GL, Solymos P, Stevens MHH, Wagner H (2015) Package vegan version 2.2-1: community ecology package. http:// cran.r-project.org/web/packages/vegan/vegan.pdf. Accessed 23 Feb 2015

Osten T (1999) The phoretic copulation of Thynninae in an ecological and evolutionary perspective (Hymenoptera, Thiphiidae). Linzer biologische Beiträge 31:755-762

Parra JRP (2014) Biological control in Brazil: an overview. Sci Agric 71:345-355. doi:10.1590/0103-9016-2014-0167

Pate VSL (1947) A conspectus of the Tiphiidae, with particular reference to the nearctic forms (Hymenoptera, Aculeata). J N Y Entomol Soc 55:115-145

Peakall R, Beattie AJ (1996) Ecological and genetic consequences of pollination by sexual deception in the orchid Caladenia tentactulata. Evolution 50:2207-2220. doi:10.2307/2410692

Peakall R, Ebert D, Poldy J, Barrow RA, Francke W, Bower CC, Schiestl FP (2010) Pollinator specific ity, floral odour chemistry and the phylogeny of Australian sexually deceptive Chiloglottis orchid simplications for pollinator-driven speciation. New Phytol 188:437-450. doi:10.1111/j.1469-8137.2010.03308.x

Peel MC, Finlayson BL, McMahon TA (2007) Updated world map of the Köppen-Geiger climate classification. Hydrol Earth Syst Sci 11:1633-1644. doi:10.5194/hess

Pereira JAA, Oliveira-Filho AT, Lemos-Filho JP (2007) Environmental heterogeneity and disturbance by humans control much of the tree species diversity of Atlantic Montane forest fragments in SE Brazil. Biodivers Conserv 16:1761-1784. doi:10.1007/ s10531-006-9063-4

Phillips RD, Hopper SD, Dixon KW (2010) Pollination ecology and the possible impacts of environmental change in the Southwest Australian Biodiversity Hotspot. Philos Trans R Soc B 365:517528. doi:10.1098/rstb.2009.0238

Pinheiro J, Bates D, DebRoy S, Sarkar D, EISPACK R-core team (2015) Package nlme version 3.1-120: linear and nonlinear 
mixed effects models. http://cran.r-project.org/web/packages/ nlme/nlme.pdf. 23 Feb 2015

Pirard R, Treyer S (2010) Agriculture and deforestation: what role should REDD + and public support policies play? Idées Pour le débat 10:1-17

Potter DA, Rogers ME (2008) Tiphiidae Wasps (Hymenoptera Tiphiidae). In: Capinera JL (ed) Encyclopedia of entomology. Springer, New York, pp 3824-3826

Price PW (1991) Evolutionary theory of host and parasitoid interactions. Biol Control 1:83-93. doi:10.1016/1049-9644(91)90107-B

R Development Core Team (2013) R: a language and environment for statistical computing. Vienna, R Foundation for Statistical Computing. http://www.R-project.org/. Accessed 23 Feb 2015

Rafael JA, Aguiar AP, Amorim DS (2009) Knowledge of insect diversity in Brazil: challenges and advances. Neotrop Entomol 38:565-570

Ranta P, Blom T, Niemela J, Joensuu E, Siitonen M (1998) The fragmented Atlantic rain forest of Brazil: size, shape and distribution of forest fragments. Biodivers Conserv 7:385-403. doi:10.1023/A:1008885813543

Ribeiro MC, Metzger JP, Martensen AC, Ponzoni FJ (2009) The Brazilian Atlantic Forest: how much is left, and how is the remaining forest distributed? Implications for conservation. Biol Conserv 142:1141-1153. doi:10.1016/j.biocon.2009.02.021

Ribeiro MC, Martensen AC, Metzger JP, Tabarelli M, Scarano F, Fortin MJ (2011) The Brazilian Atlantic Forest: a shrinking biodiversity hotspot. In: Habil JC, Zachos FE (eds) Biodiversity hotspots distribution and protection of conservation priority areas. Springer, Heidelberg, pp 405-434

Ridsdill Smith TJ (1970a) The behaviour of Hemithynnus hyalinatus (Hymenoptera: Tiphiidae), with notes on some other Thynninae. Aust J Entomol 9:171-238

Ridsdill Smith TJ (1970b) The biology of Hemithynnus hyalinatus (Hymenoptera: Tiphiidae), a parasite on scarabaeid Larvae. J Aust Entomol Soc 9:183-195

Rohani P, Miramontes O (1995) Host-parasitoid metapopulations: the consequences of parasitoid aggregation on spatial dynamics and searching efficiency. Proc R Soc Lond B Biol Sci 260:335-342

Rosenzweig ML (1995) Species diversity in space and time. Cambridge University Press, Cambridge

Rosindell J, Hubbell SP, Etienne RS (2011) The unified neutral theory of biodiversity and biogeography at age ten. Trends Ecol Evol 26:340-348. doi:10.1016/j.tree.2011.03.024

Rosindell J, Hubbell SP, He F, Harmon LJ, Etienne RS (2012) The case for ecological neutral theory. Trends Ecol Evol 27:203-208. doi:10.1016/j.tree.2012.01.004

Rouget M, Cowling RM, Lombard AT, Knight AT, Kerley GIH (2006) Designing large-scale conservation corridors for pattern and process. Conserv Biol 20:549-561. doi:10.1111/j.15231739.2006.00297.x

Santos EF, Brandão CRF (2011) Structure of wasp assemblage (Insecta: Hymenoptera, Vespoidea): taxonomic and functional diversity, and spatial organization along an elevational gradiente in the Atlantic Rain Forest, Brazil. VDM Verlag Dr. Müller, Saarbrücken

Santos BA, Peres CA, Oliveira MA, Grillo A, Alves-Costa CP, Tabarelli M (2008) Drastic erosion in functional attributes of tree assemblages in Atlantic forest fragments of northeastern Brazil. Biol Conserv 141:249-260. doi:10.1016/j.biocon.2007.09.018

Santos EF, Noll FB, Brandão CRF (2014) Functional and taxonomic diversity of stinging wasps in Brazilian Atlantic Rainforest areas. Neotrop Entomol 43:97-105. doi:10.1007/s13744-013-0183-8

Scarano FR (2002) Structure, function and floristic relationships of plant communities in stressful habitats marginal to the Brazilian Atlantic rainforest. Ann Bot 90:517-524

Schoener TW (2010) The MacArthur-Wilson Equilibrium Model. In: Losos JB, Ricklefs RE (eds) The theory of Island biogeography revisited. Princeton University Press, Pricenton, pp 52-87

Shackelford GE, Steward PR, German RN, Sait SM, Benton TG (2015) Conservation planning in agricultural landscapes: hotspots of conflict between agriculture and nature. Divers Distrib 21:357-367. doi:10.1111/ddi.12291

Soares AFS, Leão MMD, Faria VHF, Costa MCM, Moura ACM, Ramos VDV, Neto MRV, Costa EP (2013) Occurrence of pesticides from coffee crops in surfasse water. Rev Ambiente Água 8:62-72. doi:10.4136/ambi-agua.1053

Sodhi NS, Kohl LP, Brook BE, Ng PKL (2004) Southeast Asian biodiversity: an impending disaster. Trends Ecol Evol 19:654660. doi:10.1016/j.tree.2004.09.006

Stoutamire WF (1983) Wasp-pollinated species of Caladenia (Orchidaceae) in south-western Australia. Aust J Bot 31:383-394. doi:10.1071/BT9830383

Tabarelli M, Silva JMC, Gascon C (2004) Forest fragmentation, synergisms and the impoverishment of neotropical forests. Biodivers Conserv 13:1419-1425

Tabarelli M, Aguiar AV, Ribeiro MC, Metzger JP, Peres CA (2010) Prospects for biodiversity conservation in the Atlantic Forest: lessons from aging human-modified landscapes. Biol Conserv 143:2328-2340. doi:10.1016/j.biocon.2010.02.005

Tewksbury JJ, Levey DJ, Haddad NM, Sargent S, Orrock JL, Weldon A, Danielson BJ, Brinkerhoff J, Damschen E, Townsend P (2002) Corridors affect plants, animals, and their interactions in fragmented landscapes. Proc Natl Acad Sci USA 99:1292312926. doi:10.1073/pnas.202242699

Walde SJ, Murdoch WW (1988) Spatial density dependence in parasitoids. Annu Rev Entomol 33:441-466. doi:10.1146/ annurev.en.33.010188.002301

Wilson HB, Hassell MP (1997) Host-parasitoid spatial models: the interplay of demographic stochasticity and dynamics. Proc R Soc Lond B Biol Sci 264:1189-1195

Wood S (2014) Package mgcv version 1.8-4: Mixed Gam computation vehicle with GCV/AIC/REML smoothness estimation. http://cran.r-project.org/web/packages/mgcv/mgcv.pdf. Accessed 23 Feb 2015

Yahner RH (1988) Changes in wildlife communities near edges. Conserv Biol 2:333-339

Zillio T, Volkov I, Banavar JR, Hubbell SP, Maritan A (2005) Spatial scaling in model plant communities. Phys Rev Lett 95:0981011-098101-4

Zipkin EF, DeWan A, Royle JA (2009) Impacts of forest fragmentation on species richness: a hierarchical approach to community modelling. J Appl Ecol 46:815-822. doi:10.1111/j.1365-2664. 2009.01664.x 